\title{
Mentor Functions and Outcomes: A Comparison of Men and Women in Formal and Informal Mentoring Relationships
}

\author{
Belle Rose Ragins \\ University of Wisconsin-Milwaukee
}

\author{
John L. Cotton \\ Marquette University
}

\begin{abstract}
The authors examined the effects of the type of mentoring relationship and the gender composition of the relationship on mentoring functions and career outcomes reported by 352 female and 257 male protégés. Protégés of informal mentors viewed their mentors as more effective and received greater compensation than protégés of formal mentors. Protégés with informal mentors also received more career outcomes than nonmentored individuals, but no significant differences were found between nonmentored and formally mentored individuals. The gender composition of the relationship affected mentoring functions and outcomes, and protégé gender interacted with the type of relationship to affect mentoring functions.
\end{abstract}

Mentoring relationships are a critical career resource for employees in organizations. Mentors are individuals with advanced experience and knowledge who are committed to providing upward support and mobility to their protégé's careers (Hunt \& Michael, 1983; Kram, 1985a). Mentors help their protégés by providing two general types of behaviors or functions: career development functions, which facilitate the protégé's advancement in the organization, and psychosocial functions, which contribute to the protégé's personal growth and professional development (Kram, 1985a). The presence of a mentor is associated with an array of positive career outcomes: Protégés receive more promotions (Dreher \& Ash, 1990; Scandura, 1992), have higher incomes (Chao, Walz, \& Gardner, 1992; Dreher \& Ash, 1990; Whitely, Dougherty, \& Dreher, 1991), and report more mobility (Scandura, 1992) and career satisfaction (Fagenson, 1989) than nonprotégés. Mentoring has also been found to have a positive impact on organizational socialization (Ostroff \& Kozlowski, 1993), job satisfaction (Koberg, Boss, Chappell, \& Ringer, 1994), and reduced turnover intentions (Viator \& Scandura, 1991).

Belle Rose Ragins, School of Business Administration, University of Wisconsin-Milwaukee; John L. Cotton, Department of Management, Marquette University.

An earlier version of this article was presented at the meeting of the National Academy of Management, August 1998, San Diego, California, and received the Best Applied Paper Award in the Careers Division. This study was funded by a 1991 grant from the Women's Bureau of the U.S. Department of Labor.

Correspondence concerning this article should be addressed to Belle Rose Ragins, School of Business Administration, P.O. Box 742 , University of Wisconsin, Milwaukee, Wisconsin 53201 . Electronic mail may be sent to Ragins@uwm.edu.
Many organizations recognize the important benefits of mentoring and have attempted to replicate informal mentoring relationships by creating formal mentoring programs (Burke \& McKeen, 1989; Geiger-DuMond \& Boyle, 1995; Zey, 1985). One key difference between formal and informal mentoring relationships is that informal mentoring relationships develop spontaneously, whereas formal mentoring relationships develop with organizational assistance or intervention-usually in the form of voluntary assignment or matching of mentors and protégés. A second distinction is that formal relationships are usually of much shorter duration than informal relationships (Douglas, 1997).

Although it is clear that formal and informal mentoring relationships differ in how they are formed and the length of the relationship, there is little research on whether formal and informal relationships differ in the functions mentors provide or the career outcomes protégés obtain during the mentoring relationship. Many organizations simply assume that formal relationships are as effective as informal relationships and implicitly offer their employees formal relationships as a substitute for informal mentoring relationships (Keele, Buckner, \& Bushnell, 1987; Kram \& Bragar, 1992). Moreover, formal mentoring programs are being implemented across the nation: It is estimated that a third of the nation's major companies have a formal mentoring program (Bragg, 1989), and this figure is expected to continue to increase (Murray, 1991). These formal mentoring programs are being developed without the benefit or guidance of empirical research.

This situation has particular relevance for women, who face greater barriers to developing informal mentoring relationships than men (Ragins \& Cotton, 1991) and may therefore be more likely to seek formal relationships as a 
substitute for informal mentoring relationships. Additionally, many organizations target women for formal mentoring programs in the attempt to help them advance in the organization and break through the "glass ceiling" (Catalyst, 1993; Herry, 1994; Kram \& Hall, 1996; Scott, 1992). However, these organizations may not be helping their female employees if formal mentors are less effective than informal mentors.

Accordingly, the first and primary purpose of this study is to compare the mentoring functions and career outcomes associated with formal and informal mentoring relationships. A second purpose of this study is to understand whether the gender composition of the relationship affects the relationship's functions and outcomes and whether this effect varies by the type of mentoring relationship. As discussed earlier, many organizations develop formal mentoring programs that focus either exclusively or primarily on their female employees. The assignment of a male or female mentor may produce different outcomes from the relationship (Ragins, 1989) and may therefore be an important factor to consider in the development of a formal mentoring program. This study's objective, therefore, is to provide timely information for organizations seeking to develop mentoring programs and to contribute to the knowledge base necessary for emerging mentorship theory.

\section{Literature Review and Hypotheses}

\section{Mentor Functions}

According to Kram's mentor role theory (1985a), mentors can provide two broad categories of mentor functions. First, they provide career development functions, which help protégés learn the ropes and facilitate the protégé's advancement in the organization. Kram (1985a) theorized that mentors can provide five specific career development functions: sponsoring promotions and lateral moves (sponsorship); coaching the protégé (coaching); protecting the protégé from adverse forces (protection); providing challenging assignments (challenging assignments); and increasing the protégé's exposure and visibility (exposure).

Psychosocial functions compose the second broad category of mentor functions. These behaviors address interpersonal aspects of the mentoring relationship and enhance the protégés sense of competence, self-efficacy, and professional and personal development. Career development functions depend on the mentor's power and position in the organization, whereas psychosocial functions depend on the quality of the interpersonal relationship and the emotional bond that underlies the relationship. Career development functions focus on the organization and the protégé's career, whereas psychosocial functions affect the protégé on a more personal level and extend to other spheres of life, such as the protégé's personal development. Kram (1985a) theorized that mentors may provide four psychosocial functions: helping the protégé develop a sense of professional self (acceptance and confirmation), providing problem-solving and a sounding board (counseling), giving respect and support (friendship), and providing identification and role modeling (role modeling). It is important to note that mentoring is not an all or none phenomenon; a given mentor may provide all of just some of these functions.

\section{Formal and Informal Mentoring Relationships}

There are distinct differences between formal and informal mentoring relationships that may impact the mentor's functions and the career outcomes of the relationship. These differences involve the way the relationship is initiated, the structure of the relationship, and the processes involved in the relationship.

Initiation of relationship. Informal mentoring relationships develop on the basis of mutual identification and the fulfillment of career needs. Mentors select protégés who are viewed as younger versions of themselves, and the relationship provides mentors with a sense of generativity, or contribution to future generations (Erikson, 1963). Mentors are usually in mid-career stages that involve reassessment of life accomplishments (Erikson, 1963; Kram, 1985a; Levinson, Darrow, Klein, Levinson, \& McKee, 1978), and generativity helps mentors avoid stagnation and allows them to progrešs to the next life stage. Protégés select mentors who are viewed as role models. Protégés are in early career stages that involve developing a sense of professional identity, and role modeling helps protégés advance through this stage. This mutual identification leads to the often-cited intensity of the informal relationship and the parallels drawn between mentoring and parent-child relationships.

Informal mentoring relationships also develop on the basis of perceived competence and interpersonal comfort (Allen, Poteet, \& Burroughs, 1997; Kalbfleisch \& Davies, 1993; Kram, 1983, 1985a; Olian, Carroll, \& Giannantonio, 1993; Olian, Carroll, Giannontonio, \& Feren, 1988). Mentors tend to select high-performing protégés who are considered rising stars or even diamonds in the rough. Similarly, protégés select mentors with desired expertise. Members of informal mentoring relationships select partners they enjoy working with and often report a mutual attraction or chemistry that sparks the development of the relationship (Kram, 1983, 1985a).

In contrast, members of formal mentoring relationships are typically assigned to one another by a program coordinator on the basis of application forms submitted by the potential mentor and protégé (Douglas, 1997; Gaskill, 1993; Murray, 1991). In many cases, the mentor and protégé do not even meet until after the match has been made. Thus, in contrast to informal relationships, identification, role modeling, and interpersonal comfort do not play a role in the 
development of formal relationships. It is therefore reasonable to expect that the psychosocial functions of role modeling, friendship, and counseling may be less in formal than informal mentoring relationships. Formal mentoring relationships are also less likely to be founded on mutual perceptions of competency and respect. Formal mentors are selected on the basis of their competency, but this judgment is made by the program coordinator rather than the protégé (Gaskill, 1993; Murray, 1991; Phillips-Jones, 1983). Additionally, formal mentors may view their protégés as at-risk performers who enter the program because they need remedial attention (Ragins, 1997a). It is reasonable to expect that the acceptance and confirmation mentor functions, which are founded on respect and perceived competency, will be less in formal than informal mentoring relationships.

Structure of relationship. Formal and informal mentoring relationships differ in the length and formality in the relationship. Informal relationships last between 3 and 6 years (Kram, 1985a), whereas formal relationships are usually contracted to last between 6 months and 1 year (Murray, 1991; Zey, 1985). Members of informal relationships meet when desired, but the mode, frequency, and location of contact for formal relationships are often specified in a contract signed by both parties (Murray, 1991; Zey, 1985). The goals of formal relationships are specified at the start of the relationship and are screened by the program coordinator. In contrast, the goals of informal relationships evolve over time and adapt to the career needs of the individuals.

There are three potential outcomes of these different structures. First, informal mentoring relationships have more time to build psychosocial and career development functions. Mentoring may not have an immediate effect on career outcomes; it may take time for the benefits of mentoring to materialize. Kram (1985a) theorized that the benefits of mentoring extend beyond the duration of the relationship, and Chao (1997) found that the advantages of being mentored continue over time. This time-lag effect is particularly relevant when considering promotions and compensation, which usually change only once a year. Therefore, informal mentors' career interventions may have more time to reach fruition than formal mentors' career interventions.

Second, protégés in formal relationships may perceive that their mentors spend time with them because of a commitment to the mentoring program and the organization, rather than because of personal commitment to the protégé, or because the mentor believes in the protégé's potential. Both parties recognize that the relationship is short-term and that the mentor may be assigned to another protége after the relationship is over. These factors may restrict the development of trust and emotional closeness in the relationship and the provision of psychosocial functions.

Third, formal relationships are contracted to focus on career goals that are short-term and relate to the protégé's current position (Geiger-DuMond \& Boyle, 1995; Gray, 1988; Murray, 1991). In contrast, informal mentors are concerned with the long-term career needs of their protégés; in some cases the protégé's needs may take precedence over the needs of the organization, and the mentor may recommend that the protégé move to another organization. Informal mentoring relationships are therefore more aligned with the view that careers no longer unfold within a single organization but instead become "boundaryless" in spanning many different organizational settings (cf. Arthur \& Rousseau, 1996; Hall \& Mirvis, 1996).

Processes in relationship. There are four additional processes that may lead to different functions in formal and informal mentoring relationships. First, formal mentors may be less motivated to be in the relationship than informal mentors (Ragins \& Cotton, 1991). As discussed earlier, formal mentors may not identify with their protégés. In addition, formal mentors may enter the relationship to be good organizational citizens rather than because of their own developmental needs. Although formal mentors may receive more organizational recognition than informal mentors, they may not be ready to be mentors, and they may be less likely to receive the internal rewards associated with mentoring (cf. Ragins \& Scandura, in press). It is therefore reasonable to expect that formal mentors may not be as motivated as informal mentors to provide career development and psychosocial functions.

Seeond, formal mentors may have less effective communication and coaching skills than informal mentors (Kram, 1985b, 1986). Protégés select informal mentors with strong communication and coaching skills (Kalbfleisch \& Davies, 1993; Olian et al., 1988). Formal mentors may be viewed as having good communication skills by program coordinators, but if the protégé does not share these perceptions, the relationship may become strained and less effective.

A third factor that may limit the effectiveness of formal mentoring relationships is that many programs match members from different departments or functional units in the attempt to avoid charges of favoritism (Douglas, 1997; Murray, 1991). This practice may impede the formal mentor's ability to intervene on the protégé's behalf and provide exposure, protection, sponsorship, and challenging assignment functions. Moreover, informal relationships often evolve on the basis of mutual interests, job functions, and career paths. Formal mentors who are in different departments or functional areas than their protégés may also have different career paths and may therefore provide less effective career counseling and role modeling for their protégés.

Finally, because formal mentors are more visible than informal mentors, they may be more self-conscious about engaging in career development behaviors that may be construed as favoritism by others in the organization. Informal mentors generally engage in such behaviors with impunity; informal mentors have been found to sponsor their 
protégés into upwardly mobile positions, give them challenging "stretch" assignments, and buffer them from adverse forces in the organization (Kram, 1983; Scandura, 1992). Because formal mentoring relationships are public relationships that are monitored by program coordinators, formal mentors may be less likely than informal mentors to intervene on their protégé's behalf.

\section{Review of Research}

As the above theoretical review indicates, formal mentors can be expected to provide less of each of the nine career development and psychosocial functions than informal mentors. Only two studies directly investigated the relationship between type of mentor and mentor functions. On the basis of existing theory, both studies proposed greater benefits for informal than formal mentoring relationships. Although the results of these studies were complementary with existing theory, only partial support for theoretical predictions was found. In a study of 212 informal and 53 formal protégés, Chao, Walz, and Gardner (1992) found that protégés in informal mentoring relationships reported more career development functions and higher salaries than protégés in formal relationships. However, no support was found for their hypothesis that protégés in informal relationships would report more psychosocial functions than protégés in formal relationships. Fagenson-Eland, Marks, and Amendola (1997) found that informal protégés reported more psychosocial benefits than formal protégés in their study of 16 informal and 30 formal protégés employed at two merging organizations. However, informal and formal protégés did not significantly differ in reports of career development and role modeling functions.

These studies, although groundbreaking, used only the broad categories of mentoring functions and did not provide an in-depth investigation of the nine specific mentoring functions theorized by Kram (1985a). Chao et al., (1992) used Noe's (1988) 21-item mentor functions instrument, which measures Kram's (1985a) two broad categories of career development and psychosocial functions. The career development scale consisted of 7 items that measure the protection, challenging assignment, and exposure functions, but do not include Kram's coaching and sponsorship functions. Psychosocial functions were measured using a 14item scale that omitted the friendship function and included the coaching function. The coaching function is a career development function (Kram, 1985a) but is loaded on the psychosocial factor in Noe's scale (Noe, 1988). The instrument is conceptually limited in that it does not allow for an analysis of the nine individual mentor functions because single items are used to measure many functions, and some functions are not represented in the instrument. FagensonEland and her colleagues (1997) used the Scandura and Katerburg (1988) 18-item mentoring functions question- naire, which collapsed Kram's (1985a) nine mentor functions into three broad categories: career development, psychosocial, and role modeling. However, like Noe's (1988) instrument, this instrument assesses only the broad categories of mentor functions and therefore does not allow for a full assessment of Kram's mentor role theory by investigating the effects of each of the nine individual mentor functions.

One objective of the present study, therefore, was to extend this prior research by providing a more fine-grained analysis of the relationship between type of mentor and each of Kram's (1985a) mentor roles. Toward this aim, we used the Ragins and McFarlin (1990) 33-item mentor role instrument, which allows for a separate analysis of the effects of each of Kram's (1985a) nine mentor functions, as well as two additional functions.

Another objective of our study was to assess the relationship between formal and informal mentoring and career outcomes, such as promotion rate and compensation. There has been a lack of research investigating these relationships. As discussed earlier, Chao et al. (1992) explored the relationship between the type of mentoring relationship and compensation. She reported that individuals with informal mentors had greater compensation than individuals with formal mentors, but she did not investigate the relationship between type of mentor and promotion rate. We would like to replicate and extend her study by investigating the relationship between formal and informal mentoring, compensation, and promotion.

Our study also attempts to follow Chao et al.'s (1992) lead in recognizing that the effects of mentoring on career outcomes may not be immediate, but may take place over time. This is particularly relevant when investigating formal mentoring relationships. As discussed earlier, because formal mentoring relationships usually last a year or less (Murray, 1991; Zey, 1985), static measures, although suitable for capturing current perceptions of the mentor's behaviors or functions, fall short of capturing the career outcomes of the relationship; the effects of a formal mentoring relationship may not be realized for 1 or 2 years following the relationship's termination. Chao and her colleagues (1992) recognized this issue and wisely included duration of mentoring relationship as a control variable in their study. They also tested for differences between protégés with current or recent mentors and protégés who had relationships that ended 2 years prior to being surveyed. They found no differences between these groups, but they made the valuable point that it is important to examine historical effects and control for the duration of the relationship when investigating the relationship between type of mentoring and career outcomes. Toward that end, we controlled for the duration of mentoring relationship and included retrospective measures of the history of mentoring relationships in our analyses. 


\section{Hypotheses of Formal and Informal Mentoring Relationships}

On the basis of the theory and research reviewed above, we hypothesized that protégés in informal mentoring relationships would report that their mentors provide more career development and psychosocial functions than protégés in formal relationships.

Hypothesis 1 : Protégés in informal mentoring relationships will report that their mentors provide more career development functions (sponsorship, coaching, protection, challenging assignments, exposure) than protégés in formal mentoring relationships.

Hypothesis 2: Protégés in informal mentoring relationships will report that their mentors provide more psychosocial functions (acceptance and confirmation, counseling, friendship, and role modeling) than protégés in formal mentoring relationships.

We also expected that informal protégés would report more overall satisfaction with the performance of their mentor than protégés in formal relationships.

Hypothesis 3: Protégés in informal mentoring relationships will report greater satisfaction with their mentors than protégés in formal mentoring relationships.

We also expected a positive relationship between the history of prior mentoring relationships and career outcomes. In particular, protégés who had primarily informal relationships in the past should report more compensation and a higher promotion rate than protégés with a history of primarily formal relationships.

Hypothesis 4: Protégés with a history of informal mentoring relationships will receive more compensation and promotions than protégés with a history of formal relationships.

The next section explores the conjoint effects of the gender composition of the relationship and the type of mentor on mentor functions and career outcomes.

\section{Gender Composition of Relationship}

Existing mentorship theory holds that the gender composition of the mentoring relationship is a critical factor affecting mentoring functions and outcomes (cf. Ragins, 1997a). Ragins (1997a, 1997b) observed that social identity theory (Tajfel, 1978), the similarity-attraction paradigm (Byrne, 1971), and the relational demography perspective (Tsui, Egan, \& O'Reilly, 1992; Tsui \& O'Reilly, 1989) all predict more perceived similarity, identification and rolemodeling in same-gender as compared with cross-gender relationships. Carrying this logic to the mentoring arena, Ragins (1997a) predicted that psychosocial functions, which incorporate similarity, identification, and role mod- eling, should also be stronger in same-gender as compared with cross-gender mentoring relationships.

Hypothesis 5: Protégés in same-gender relationships will report more psychosocial functions (acceptance and confirmation, counseling, friendship, and role modeling) than protégés in cross-gender mentoring relationships.

Ragins (1997a) also proposed that mentors' power in the organization influences their ability to provide their protégés with such career development functions as sponsoring their protégés to high-ranking positions, protecting them from adverse forces, and giving them needed exposure. She proposed that because majority mentors (i.e., male mentors) generally have more power in organizations than minority mentors (i.e., female mentors), they should be better able to provide career development functions and organizational outcomes. This proposition was partially supported in a recent study by Dreher and Cox (1996), which found that protégés with male mentors received greater compensation than protégés with female mentors. However, their study did not investigate career development functions or promotion rates, or the impact of the history of mentoring relationships on compensation and promotion. We therefore wanted to build on their study and test existing theory by proposing the following hypotheses:

Hypothesis 6a: Protégés with male mentors will report more -eareer development functions (sponsorship, coaching, protection, challenging assignments, exposure) than protégés with female mentors.

Hypothesis 6b: Protégés with a history of male mentors will report more compensation and promotions than protégés with a history of female mentors.

Expanding on this framework, Ragins (1997a) proposed that compared with other gender combinations, male protégés with male mentors should receive the most benefits from the mentoring relationship; these protégés should be the most satisfied with their relationships and should receive more psychosocial and career development benefits from their relationships than any other gender combination. Correspondingly, she proposed that relationships involving minority mentors (i.e., female mentors) and majority protégés (i.e., male protégés) should be the most limited in providing mentoring functions; they are limited in providing career development functions because of the female mentor's relative lack of power, and they are limited in providing psychosocial functions because the relationship is crossgender. Existing theory (Kram, 1985a) and research (Chao et al., 1992) indicates that psychosocial and career development mentor functions are inter-related and may synergistically build on one another, thereby making the differences between these dyads even more salient (Ragins, 1997a). 
This theoretical perspective was tested by the following hypotheses:

Hypothesis 7a: Male protégés with male mentors will report more career development and psychosocial functions and more satisfaction with their mentors than any other gender combination of mentoring relationship.

Hypothesis $7 b$ : Male protégés with female mentors will report less career development and psychosocial functions and less satisfaction with their mentors than any other gender combination of mentoring relationship.

We also expected that male protégés who had primarily male mentors in the past would receive greater career outcomes than any other gender combination. Similarly, male protégés with a history of primarily female mentors should report less career outcomes than any other gender combination. These expectations are based on the theory discussed above (Ragins, 1997a), as well as on the finding of positive relationships between compensation and psychosocial and career development mentoring functions (Chao et al., 1992; Scandura, 1992).

Hypothesis 8a: Male protégés with a history of male mentors will report greater compensation and promotion than any other gender combination.

Hypothesis $8 b$ : Male protégés with a history of female mentors will report less compensation and promotion than any other gender combination.

Finally, we wanted to explore whether the gender composition of the relationship interacts with the type of relationship in influencing the mentoring relationship. Because there was no theory or research to provide direction, we tested the following research question: Does the gender composition of the relationship moderate the relationship between type of mentoring (formal vs. informal) and reports of mentor functions and satisfaction with the relationship?

To date, only one study investigated the impact of gender composition of mentoring relationships on mentor functions, and there has been no research investigating the relationship between the historical composition of the relationship and career outcomes. In a survey of 181 protégés in informal mentoring relationships, Ragins and McFarlin (1990) found that same-gender protégés reported engaging in more social activities with their mentors than crossgender protégés and that female protégés with female mentors reported more role modeling than any other gender combination. However, one limitation of this study was that a restricted sample of female mentors prevented a comparative analysis of all four gender combinations. Because this situation is relatively common in male-dominated organizations and occupations (Noe, 1988; Ragins, 1989), we obtained a sample of individuals from male-typed, femaletyped, and gender-integrated occupations to obtain adequate sample sizes for each of the four gender combinations of mentoring relationships.

In a related study, Ensher and Murphy (1997) examined the effects of race similarity among 104 minority students who were assigned to formal, same-gender mentoring relationships that lasted for 8 weeks. The researchers found that minority protégés assigned to same-race mentors reported more career development functions than minority protégés assigned to different race mentors but found no support for their prediction that psychosocial support would be greater among same-race mentors or that female mentors would provide more psychosocial support than male mentors. However, because protégés were assigned to same-gender mentors, the researchers were unable to examine the effect of the gender composition of the relationship on mentoring functions.

In this study, we examined the effects of gender composition and the type of mentoring relationship on mentoring functions and outcomes. We extended prior research and tested new theory by measuring specific mentor roles and by investigating the impact of history of mentoring relationships on career outcomes.

\section{Method}

\section{Procedure and Respondents}

Sampling procedure. One goal of our study was to investigate the effects of the gender composition of the mentoring relationship on mentor functions and outcomes. Because male-dominated occupations have a shortage of higher-ranking, female mentors (Ragins, 1989), and this study called for a sample of male protégés with female mentors, we obtained a sample of men and women in male-typed, female-typed, and gender-integrated occupations. Three occupations were selected on the basis of labor statistics and research on occupational gender-typing (Beggs \& Doolittle, 1993; U.S. Department of Commerce, 1996): engineering (maledominated), social work (female-dominated), and journalism (gender-integrated). Formal mentoring programs are used in all three of these occupations (Paine, 1986; Smith, Chase, \& Byrd, 1986; Taibbi, 1983).

We obtained a national random sample by using mailing lists of national professional associations representing these three occupations. To obtain a gender-balanced sample, equal numbers of male and female names were randomly selected from each mailing list. A total of 3,000 surveys were mailed; 1,000 ( 500 to men, 500 to women) were sent to each of the three occupations. Follow-up surveys and reminder letters were sent according to a modified version of the Dillman mail survey method (Dillman, 1978). A total of 1,258 surveys were returned, for a response rate of $42 \%$. Self-employed and retired employees were excluded from analyses. Relatively complete data for analyses were available for 1,162 respondents.

Respondents. Respondents consisted of 654 women and 500 men; 8 respondents did not report their gender. The occupational breakdown of the respondents consisted of 362 journalists (31.2\%), 414 social workers (35.6\%), and 386 engineers (33.2\%). 
We used an established definition of mentor (Ragins, 1989) in our survey: "A mentor is generally defined as a higher ranking, influential individual in your work environment who has advanced experience and knowledge and is committed to providing upward mobility and support to your career. Your mentor may or may not be in your organization and s/he may or may not be your immediate supervisor." Formal mentoring was defined as follows: "In order to assist individuals in their development and advancement, some organizations have established formal mentoring programs, where protégés and mentors are linked in some way. This may be accomplished by assigning mentors or by just providing formal opportunities aimed at developing the relationship. To recap: Formal mentoring relationships are developed with organizational assistance. Informal mentoring relationships are developed spontaneously, without organizational assistance." To ensure that respondents had a clear understanding of the distinction between formal and informal mentors, we asked respondents to describe their formal mentoring program immediately following the question asking them to identify whether their mentor was formal or informal. We also asked the respondents to describe the history of their mentoring relationships over the last 10 years, starting with their most recent mentor. For each relationship, we asked the respondents to give information on the mentor's gender, the type of relationship (formal/informal), the mentor's position (supervisory/nonsupervisory), and the duration of the relationship.

On the basis of these definitions, 510 respondents (43.9\%) reported having an informal mentor, 104 respondents (9\%) reported having a formal mentor, and $548(47.2 \%)$ did not have a mentor. The final sample was composed of these 614 protégés, which consisted of 352 female protégés, 257 male protégés, and 5 who did not report their gender. Although men and women did not significantly differ in having a mentor, $\chi^{2}(1, N=1,135)=0.36$, $n s$, men were nearly twice as likely to be in a formal mentoring relationship: $22 \%$ of the men reported currently being in a formal relationship, compared with $12 \%$ of the women in the sample, $\chi^{2}(1, N=608)=10.39, p<.001$. Men were also significantly more likely than women to have a history of formal mentoring relationships: $18.5 \%$ of the men reported having primarily formal mentors in their past, compared with $9.7 \%$ of the women, $\chi^{2}(1$, $N=579)=9.37, p<.01$. One implication of these gender differences is that if the type of mentoring relationship does affect mentoring functions and outcomes as proposed, the type of mentoring relationship should be included as a control variable when testing the gender composition hypotheses.

The sample involved $348(57.1 \%)$ individuals in same-gender relationships and $261(42.9 \%)$ in cross-gender relationships. A more fine-grained breakdown revealed 233 male protégés with male mentors, 115 female protégés with female mentors, 24 male protégés with female mentors, and 237 female protégés with male mentors. The median length of the current mentoring relationship was 4.0 years, and the average length was 6.7 years. The current mentoring relationship for male protégés was significantly longer than for female protégés, $t(426)=-2.77, p<.01$, indicating that this yariable should also be used as a control variable in the analysis. Fifty-three percent of the protégés reported that their mentors were also their supervisors, and there were no significant gender differences on this variable, $\chi^{2}(1, N=611)=1.06$, ns. The average age of the protégés was 46 years, and $92 \%$ were Cauca- sian. Most were married (70\%) and had completed $(63 \%)$ or pursued (12\%) graduate degrees.

\section{Measures}

History of mentoring relationships. We asked our respondents to give information about each mentoring relationship they had over the last 10 years, as well as their current mentoring relationship. They were asked to report whether their prior relationships were formal or informal, the gender of their mentors, their mentors' positions, and the duration of the relationships.

The history of prior relationship type was measured by dividing the number of prior relationships that involved formal mentors by the total number of prior formal and informal mentoring relationships. Higher values therefore reflect a greater proportion of for mal than informal mentoring relationships. The history of prior gender of mentors was measured by dividing the number of prior relationships involving male mentors by the total number of relationships involving both male mentors and female mentors. Higher values thus reflect a greater proportion of male than female mentors. The history of relationships involving specific gender compositions was computed in a similar manner.

Mentor functions. The Mentor Role Instrument (MRI) was used to measure mentor functions (Ragins \& McFarlin, 1990). The 33-item instrument was developed via confirmatory factor analysis, and independently measures each of Kram's (1985a) nine mentor roles. The instrument also assesses two additional psychosocial-related roles: parent and social interactions. According to Kram (1985a), these roles may emerge in response to gender issues in mentoring relationships; protégés may seek to avoid sexual issues in cross-gender relationships by viewing their mentor as a parent figure or by avoiding informal, after-work social interactions.

The MRI has proven reliability and preliminary evidence of validity (Ragins \& McFarlin, 1990). The 33-item instrument has 3 items per mentor role and was measured on a 7-point Likert scale with responses ranging from 1 (strongly disagree) to 7 (strongly agree). The instrument may be found in the Appendix. The coefficient alphas for the eleven mentor roles ranged from .63 to .91 and are listed on the diagonal of the correlation matrix in Table 1.

Mentor satisfaction. The protégé's satisfaction with the mentor was measured by a 4-item scale. The items, which are listed in the Appendix, used the same 7-point Likert scale used in the MRI. The coefficient alpha for the satisfaction scale was .83 .

Career outcomes. Promotion rate and compensation were used to measure mentor outcomes. Using established definitions of promotions (cf. Whitely et al., 1991), promotions were defined as involving two or more of the following criteria: significant increases in annual salary, significant increases in scope of responsibility, changes in job level or rank, or becoming eligible for bonuses, incentives or stock plans. Given the above definition, respondents were asked how many promotions they received over the last 10 years. Respondents were also asked to report their current annual compensation, which included salary, bonuses, commissions, stock options, and profit sharing.

Control variables. Six variables that may be related to promotion rate and compensation were considered as potential covariates: organizational rank, organizational tenure, position tenure, number of career interruptions, education, and occupation (engi- 


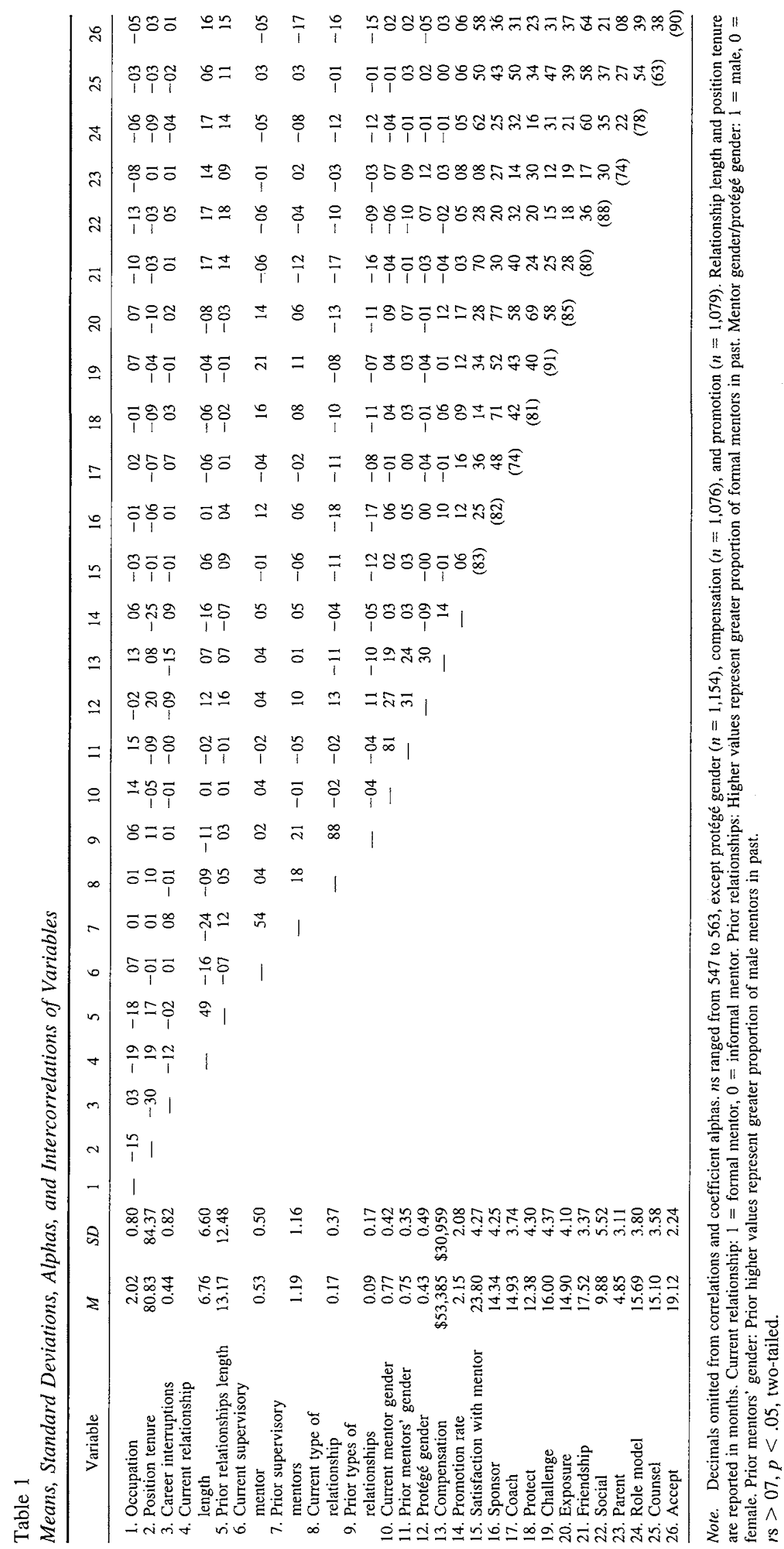


neering, social work, and journalism). We also considered six other mentoring variables that have been found to be related to mentor roles and outcomes in other studies (cf. Burke \& McKeen, 1997; Chao et al., 1992; Ragins \& McFarlin, 1990; Whitely et al., 1991). These variables included whether the mentor is the protégé's supervisor, the length of the mentoring relationship, the average number of hours spent in the relationship per month, the number of prior mentoring relationships, the protégé's age, and the protégé's socioeconomic background.

To preserve power, covariates were selected that had significant correlations with dependent variables but low intercorrelations (Neter \& Wasserman, 1974). Tests were made of all control variables by independent interaction terms to test homogeneity of regression assumptions fundamental to covariance analyses. On the basis of these criteria, the protégé's occupation (engineering, social work, journalism), the duration of their current mentoring relationship (converted to months), and whether their current mentor was their supervisor were selected as covariates for analyses that involved reports of the current mentor's functions and satisfaction with the current mentor. For analyses assessing the relationship between the prior history of mentoring relationships and career outcomes, covariates included occupation, position tenure, the number of career interruptions, the duration of prior mentoring relationships, and the number of those relationships involving supervisory mentors.

\section{Results}

\section{Analyses}

The correlations, means, standard deviations, and coefficient alphas for the study variables are displayed in Table 1. Hierarchical multiple regression analyses and a priori planned group contrasts were used to test the study's hypotheses.

Separate hierarchical regression analyses were conducted for each of the dependent variables. For hierarchical analyses involving the dependent variables of mentoring functions and satisfaction with the mentor, independent variables were entered in the following order: (a) the control variables; (b) type of relationship, that is, whether the current relationship was formal or informal (Hypotheses 1, 2, and 3); (c) the current mentor's gender (Hypothesis 6a) and the protégé's gender; (d) the two-way interactions involving mentor gender, protégé gender, and the type of relationship; and (e) the three-way interaction involving mentor gender, protégé gender, and the type of relationship (Research Question). Hypotheses that assessed the relationship between the history of the mentoring relationship and career outcomes (promotion and compensation) were tested in a three-step hierarchical analysis in which the control variables were entered in the first step, the history of the type of mentoring relationship in the second step (Hypothesis 4), and the history of the gender composition of prior relationships in the third step (Hypothesis 6b).

Duncan's Multiple Range tests were used to test hypoth- esized differences between the adjusted group means of the four gender combinations of mentoring relationships (Hypothesis 5, Hypotheses 7a \& 7b, Hypotheses 8a \& 8b). We used hierarchical regression analyses to obtain betas for the four covariates and the type of mentoring relationship (formal vs. informal); we then used these betas to compute the adjusted means.

\section{Mentoring Control Variables}

Both of the mentoring control variables were significantly related to the dependent variables. Mentors who were supervisors provided more career development functions than nonsupervisory mentors, but no significant differences were found for psychosocial functions. The length of the mentoring relationship was positively related to compensation and psychosocial functions but was unrelated to career development functions.

\section{Comparisons of Informal and Formal Mentoring Relationships}

As displayed in Table 2, the significant negative beta for the type of relationship term indicates full support for Hypotheses 1 , which predicted that protégés with informal mentors would report more career development functions (sponsoring, coaching, protection, challenging assignments, and exposure) than protégés with formal mentors. Hypotheses 2 predicted that protégés with informal mentors would report more psychosocial functions than protégés with formal mentors. As shown in Table 3, this hypothesis received support for four of the six psychosocial functions. Protégés with informal mentors reported that their mentors provided more psychosocial functions involving friendship, social support, role modeling, and acceptance than protégés with formal mentors. However, no significant differences were found on reports of the parent and counseling functions. Full support was also received for our prediction (Hypothesis 3 ) that protégés with informal mentors would report greater satisfaction with their mentors than protégés in formal relationships.

Partial support was received for Hypothesis 4. In support of our prediction, the hierarchical regression analyses revealed that individuals with a history of informal mentors had significantly greater compensation $(M=\$ 56,629)$ than individuals with a history of formal mentors $(M=$ $\$ 48,107$ ). Although those with a history of informal mentors also had more promotions over the last 10 years $(M=2.55)$ than those with a history of formal mentors $(M=2.04)$, the differences were not significant when controlling for differences in position tenure, number of career interruptions, occupation, supervisory status of mentors, and length of mentoring relationships over the last 10 years. The results of these analyses are shown in Table 4 . 
Table 2

Summary of Hierarchical Regression Analysis for Variables Predicting Career Development Mentoring Functions (Hypothesis 1, Hypothesis 6a, and Research Question)

\begin{tabular}{|c|c|c|c|c|c|}
\hline Mentor role and predictor & $B$ & $S E$ & $\beta$ & $\Delta R^{2}$ & $R^{2}$ \\
\hline \multicolumn{6}{|l|}{ Sponsor $(n=567)$} \\
\hline Step 1: Control variables & & & & & $.01^{*}$ \\
\hline Supervisory mentor & 1.07 & 0.36 & $.12 * *$ & & \\
\hline Relationship length & 0.02 & 0.03 & .03 & & \\
\hline Occupation & -0.03 & 0.23 & -.01 & & \\
\hline Step 2 & & & & $.03 * * *$ & $.05^{* * *}$ \\
\hline $\mathrm{RT}$ & -2.05 & 0.47 & $-.18^{* * * *}$ & & \\
\hline Step 3 & & & & .002 & $.05^{* * *}$ \\
\hline MG & 0.52 & 0.44 & .05 & & \\
\hline PG & 0.02 & 0.37 & .00 & & \\
\hline Step 4 & & & & .00 & $.05^{* * *}$ \\
\hline$\dot{M} G \times P G$ & -0.07 & 1.51 & -.01 & & \\
\hline $\mathrm{RT} \times \mathrm{MG}$ & -0.58 & 1.23 & -.04 & & \\
\hline $\mathrm{RT} \times \mathrm{PG}$ & 1.29 & 1.22 & .07 & & \\
\hline Step 5 & & & & .002 & $.05 * * *$ \\
\hline $\mathrm{MG} \times \mathrm{PG} \times \mathrm{RT}$ & 3.33 & 3.23 & .16 & & \\
\hline \multicolumn{6}{|l|}{ Coach $(n=567)$} \\
\hline Step 1: Control variables & & & & & .006 \\
\hline Supervisory mentor & -0.37 & 0.32 & -.05 & & \\
\hline Relationship length & -0.04 & 0.02 & -.07 & & \\
\hline Occupation & 0.06 & 0.21 & .01 & & \\
\hline Step 2 & & & & $.01^{* *}$ & $.02 *$ \\
\hline $\mathrm{RT}$ & -1.15 & 0.42 & $-.12^{* *}$ & & \\
\hline Step 3 & & & & .00 & .02 \\
\hline $\mathrm{MG}$ & -0.03 & 0.39 & -.00 & & \\
\hline PG & -0.13 & 0.33 & -.02 & & \\
\hline Step 4 & & & & $.02 * *$ & $.04 * *$ \\
\hline $\mathrm{MG} \times \mathrm{PG}$ & 2.71 & 1.34 & $.31^{*}$ & & \\
\hline $\mathrm{RT} \times \mathrm{MG}$ & -0.53 & 1.09 & -.05 & & \\
\hline $\mathrm{RT} \times \mathrm{PG}$ & 2.95 & 1.08 & $\approx .19 * *$ & & \\
\hline Step 5 & & & & .003 & $.04 * *$ \\
\hline$\hat{\mathrm{MG}} \times \mathrm{PG} \times \mathrm{RT}$ & 4.18 & 2.85 & .24 & & \\
\hline \multicolumn{6}{|l|}{ Protect $(n=564)$} \\
\hline Step 1: Control variables & & & & & $.03 * *$ \\
\hline Supervisory mentor & 1.31 & 0.36 & $.15^{* * *}$ & & \\
\hline Relationship length & -0.02 & 0.03 & -.04 & & \\
\hline Occupation & -0.12 & 0.23 & -.02 & & \\
\hline Step 2 & & & & $.01 * *$ & $.04^{* * *}$ \\
\hline RT & -1.28 & 0.48 & $-.11 * *$ & & \\
\hline Step 3 & & & & .001 & $.04 * * *$ \\
\hline MG & 0.43 & 0.45 & .04 & & \\
\hline PG & -0.10 & 0.38 & -.01 & & \\
\hline Step 4 & & & & .001 & $.04 * *$ \\
\hline $\mathrm{MG} \times \mathrm{PG}$ & -0.48 & 1.54 & -.05 & & \\
\hline $\mathrm{RT} \times \mathrm{MG}$ & 0.05 & 1.25 & .004 & & \\
\hline $\mathrm{RT} \times \mathrm{PG}$ & 1.07 & 1.24 & .06 & & \\
\hline Step 5 & & & & .000 & $.04 * *$ \\
\hline $\mathrm{MG} \times \mathrm{PG} \times \mathrm{RT}$ & -1.36 & 3.29 & -.007 & & \\
\hline \multicolumn{6}{|l|}{ Challenge $(n=568)$} \\
\hline Step 1: Control variables & & & & & $.05^{* * *}$ \\
\hline Supervisory mentor & 1.80 & 0.36 & $.20^{* * *}$ & & \\
\hline Relationship Iength & 0.00 & 0.03 & .003 & & \\
\hline Occupation & 0.32 & 0.23 & .05 & & \\
\hline Step 2 & & & & $.01^{*}$ & $.06 * * *$ \\
\hline RT & -1.05 & 0.48 & $-.09 *$ & & \\
\hline Step 3 & & & & .002 & $.06 * * *$ \\
\hline MG & 0.39 & 0.45 & .04 & & \\
\hline PG & -0.42 & 0.38 & -.05 & & \\
\hline Step 4 & & & & .005 & $.06 * * *$ \\
\hline $\mathrm{MG} \times \mathrm{PG}$ & 0.40 & 1.55 & .04 & & \\
\hline $\mathrm{RT} \times \mathrm{MG}$ & -0.23 & 1.25 & -.02 & & \\
\hline $\mathrm{RT} \times \mathrm{PG}$ & 2.16 & 1.25 & .12 & & \\
\hline Step 5 & & & & $.006^{*}$ & $.07 * * *$ \\
\hline$\hat{\mathrm{MG}} \times \mathrm{PG} \times \mathrm{RT}$ & 6.52 & 3.28 & $.32 *$ & & \\
\hline
\end{tabular}


Table 2 (continued)

\begin{tabular}{|c|c|c|c|c|c|}
\hline Mentor role and predictor & $B$ & $S E$ & $\beta$ & $\Delta R^{2}$ & $R^{2}$ \\
\hline \multicolumn{6}{|l|}{ Exposure $(n=567)$} \\
\hline Step 1: Control variables & & & & & $.02 * *$ \\
\hline Supervisory mentor & 1.04 & 0.35 & $.13 * *$ & & \\
\hline Relationship length & -0.03 & 0.03 & -.05 & & \\
\hline Occupation & 0.26 & 0.22 & .05 & & \\
\hline Step 2 & & & & $.02 * * *$ & $.04 * * *$ \\
\hline RT & -1.60 & 0.45 & $-.15 * * *$ & & \\
\hline Step 3 & & & & .006 & $.05^{* * *}$ \\
\hline MG & 0.79 & 0.42 & .08 & & \\
\hline PG & -0.05 & 0.36 & -.01 & & \\
\hline Step 4 & & & & .001 & $.05 * * *$ \\
\hline $\mathrm{MG} \times \mathrm{PG}$ & -0.023 & 1.46 & -.002 & & \\
\hline $\mathrm{RT} \times \mathrm{MG}$ & 0.62 & 1.18 & .05 & & \\
\hline $\mathrm{RT} \times \mathrm{PG}$ & 0.01 & 1.18 & .00 & & \\
\hline Step 5 & & & & .000 & $.05 * * * *$ \\
\hline $\mathrm{MG} \times \mathrm{PG} \times \mathrm{RT}$ & 1.43 & 3.11 & .07 & & \\
\hline
\end{tabular}

Note. Dummy coding of predictors: supervisory mentor: $1=$ supervisory, $0=$ not supervisor. Relationship type $(\mathrm{RT}): 1=$ formal mentor, $0=$ informal mentor. Mentor gender $(\mathrm{MG}): 1=$ male, $0=$ female. Protégé gender $(\mathrm{PG}): 1=$ male, $0=$ female.

$* p \leq .05 . \quad * * p<.01 . * * * p<.001$.

\section{Effect of Gender on Mentoring Relationships}

As discussed earlier, because men were significantly more likely to have formal mentors than women, and the type of mentoring relationship was found to be related to mentoring and career outcomes, the type of mentoring relationship needed to be controlled for when investigating gender effects in mentoring relationships. Therefore, type of mentoring relationship was entered hierarchically before gender terms in the regression analyses, and the group means were adjusted for type of mentor in the planned group contrasts.

Effect of same-gender relationships. We predicted (Hypothesis 5) that individuals in same-gender mentoring relationships would report more psychosocial functions than individuals in cross-gender relationships. We tested this hypothesis by using the Duncan's Multiple Range test. The adjusted group means for all gender combinations are displayed in Table 5. Although the means generally were in the direction predicted, Hypothesis 5 was not supported. However, there was evidence that the gender composition of the relationship affected two psychosocial functions. Specifically, female protégés with female mentors were significantly more likely to report engaging in social activities with their mentors than female protégés with male mentors. Male protégés with female mentors were significantly less likely than all other gender combinations to report that their mentor provided acceptance roles.

Effect of male mentors. As displayed in Table 2, no support was found for Hypothesis $6 \mathrm{a}$, which held that male mentors would be associated with more career development functions than female mentors. Partial support was received for Hypothesis $6 \mathrm{~b}$, which held that protégés with a history of male mentors would report more compensation and promotions than protégés with a history of female mentors. When controlling for differences in position tenure, number of career interruptions, occupation, length of mentoring relationships, supervisory status of mentors, and the type of mentor (formal vs. informal), the hierarchical regression analyses revealed that protégés with a history of male mentors received significantly greater compensation $(M=$ $\$ 60,140)$ than protégés with a history of female mentors $(M=\$ 41,354)$. Protégés with a history of male mentors also reported more promotions over the last 10 years $(M=2.6)$ than those with a history of female mentors $(M=2.3)$, but these differences were not statistically significant. The results of these analyses are shown in Table 4.

Effect of other gender combinations. We used the Duncan's Multiple Range test to test Hypotheses 7a and 7b, and the results of these analyses are shown in Table 5. Contrary to our predictions (Hypothesis $7 \mathrm{a}$ ), male protégés with male mentors did not report more mentoring functions or satisfaction with their mentors than any other gender combination. However, some support was found for Hypothesis $7 \mathrm{~b}$, which predicted that male protégés with female mentors would report fewer functions and less satisfaction than any other gender combination. The general pattern of means revealed that male protégés with female mentors reported less psychosocial and career development functions than the other gender combinations, but these effects were only significant for three of the mentor roles and the mentor satisfaction variable. Compared with other gender combinations, male protégés with female mentors were less sat- 
Table 3

Summary of Hierarchical Regression Analysis for Variables Predicting Mentor Satisfaction and Psychosocial Mentoring Functions (Hypothesis 2, Hypothesis 3, and Research Question)

\begin{tabular}{|c|c|c|c|c|c|}
\hline Mentor role and predictor & $B$ & $S E$ & $\beta$ & $\Delta R^{2}$ & $R^{2}$ \\
\hline \multicolumn{6}{|l|}{ Mentor satisfaction $(n=568)$} \\
\hline Step 1: Control variables & & & & & .004 \\
\hline Supervisory mentor & 0.01 & 0.36 & .001 & & \\
\hline Relationship length & 0.03 & 0.03 & .05 & & \\
\hline Occupation & -0.14 & 0.23 &.- .03 & & \\
\hline Step 2 & & & & $.01 * *$ & $.02 *$ \\
\hline $\mathrm{RT}$ & -1.25 & 0.48 & $-.11^{* *}$ & & \\
\hline Step 3 & & & & .00 & .02 \\
\hline MG & 0.23 & 0.45 & .02 & & \\
\hline PG & -0.004 & 0.38 & .00 & & \\
\hline Step 4 & & & & .008 & .02 \\
\hline $\mathrm{MG} \times \mathrm{PG}$ & 2.70 & 1.54 & .27 & & \\
\hline $\mathrm{RT} \times \mathrm{MG}$ & -1.47 & 1.25 & -.11 & & \\
\hline $\mathrm{RT} \times \mathrm{PG}$ & 1.84 & 1.24 & .10 & & \\
\hline Step 5 & & & & .000 & .02 \\
\hline $\mathrm{MG} \times \mathrm{PG} \times \mathrm{RT}$ & 0.86 & 3.28 & .04 & & \\
\hline \multicolumn{6}{|l|}{ Friendship $(n=568)$} \\
\hline Step 1: Control variables & & & & & $.03 * * *$ \\
\hline Supervisory mentor & -0.19 & 0.28 & -.03 & & \\
\hline Relationship length & 0.08 & 0.02 & $.15^{* * *}$ & & \\
\hline Occupation & -0.28 & 0.18 & -.07 & & \\
\hline Step 2 & & & & $.02 * * *$ & $.06^{* * * *}$ \\
\hline $\mathrm{RT}$ & -1.38 & 0.37 & $-.15^{* * * *}$ & & \\
\hline Step 3 & & & & .001 & $.06 * * *$ \\
\hline MG & -0.22 & 0.34 & -.03 & & \\
\hline PG & -0.13 & 0.29 & -.02 & & \\
\hline Step 4 & & & & $.02^{* *}$ & $.08 * * *$ \\
\hline $\mathrm{MG} \times \mathrm{PG}$ & 2.65 & 1.18 & $.34 *$ & & \\
\hline $\mathrm{RT} \times \mathrm{MG}$ & -1.74 & 0.96 & -.17 & & \\
\hline $\mathrm{RT} \times \mathrm{PG}$ & 2.90 & 0.95 & $.21 * *$ & & \\
\hline Step 5 & & & & .000 & $.08^{* * *}$ \\
\hline $\mathrm{MG} \times \mathrm{PG} \times \mathrm{RT}$ & -1.90 & 2.52 & -.12 & & \\
\hline \multicolumn{6}{|l|}{ Social $(n=568)$} \\
\hline Step 1: Control variables & & & & & $.04 * * *$ \\
\hline Supervisory mentor & -0.39 & 0.46 & -.03 & & \\
\hline Relationship length & 0.12 & 0.03 & $.14 * * *$ & & \\
\hline Occupation & -0.66 & 0.29 & $-.09 *$ & & \\
\hline Step 2 & & & & $.01 *$ & $.04 * * *$ \\
\hline $\mathrm{RT}$ & -1.22 & 0.61 & $-.08^{*}$ & & \\
\hline Step 3 & & & & .01 & $.05 * * *$ \\
\hline MG & -0.98 & 0.57 & -.07 & & \\
\hline$P G$ & 0.95 & 0.49 & $.08^{*}$ & & \\
\hline Step 4 & & & & $.02 *$ & $.07 * * *$ \\
\hline $\mathrm{MG} \times \mathrm{PG}$ & 4.65 & 1.94 & $.37 *$ & & \\
\hline $\mathrm{RT} \times \mathrm{MG}$ & -0.36 & 1.57 & -.02 & & \\
\hline $\mathrm{RT} \times \mathrm{PG}$ & 3.38 & 1.56 & $.15^{*}$ & & \\
\hline Step 5 & & & & .00 & $.07 * * *$ \\
\hline $\mathrm{MG} \times \mathrm{PG} \times \mathrm{RT}$ & 1.65 & 4.14 & .06 & & \\
\hline \multicolumn{6}{|l|}{ Parent $(n=568)$} \\
\hline Step 1: Control variables & & & & & $.02 * *$ \\
\hline Supervisory mentor & 0.12 & 0.26 & .02 & & \\
\hline Relationship length & 0.06 & 0.02 & $.13^{* * *}$ & & \\
\hline Occupation & -0.23 & 0.16 & -.06 & & \\
\hline Step 2 & & & & .00 & $.02 *$ \\
\hline RT & -0.15 & 0.35 & -.02 & & \\
\hline Step 3 & & & & $.01^{*}$ & $.04 * * *$ \\
\hline $\mathrm{MG}$ & 0.39 & 0.32 & .05 & & \\
\hline PG & 0.62 & 0.28 & $.10 *$ & & \\
\hline Step 4 & & & & .00 & $.04 * *$ \\
\hline$M G \times P G$ & 0.63 & 1.11 & .08 & & \\
\hline $\mathrm{RT} \times \mathrm{MG}$ & -0.72 & 0.90 & -.08 & & \\
\hline $\mathrm{RT} \times \mathrm{PG}$ & 1.61 & 0.89 & .12 & & \\
\hline Step 5 & & & & .00 & $.04 * *$ \\
\hline$M G \times P G \times R T$ & -3.37 & 2.36 & -.23 & & \\
\hline
\end{tabular}


Table 3 (continued)

\begin{tabular}{|c|c|c|c|c|c|}
\hline Mentor role and predictor & $B$ & $S E$ & $\beta$ & $\Delta R^{2}$ & $R^{2}$ \\
\hline \multicolumn{6}{|l|}{ Role model $(n=568)$} \\
\hline Step 1: Control variables & & & & & $.03 * * *$ \\
\hline Supervisory mentor & -0.23 & 0.32 & -.03 & & \\
\hline Relationship length & 0.09 & 0.02 & $.15^{* * *}$ & & \\
\hline Occupation & -0.14 & 0.20 & -.03 & & \\
\hline Step 2 & & & & $.01 *$ & $.04 * * *$ \\
\hline RT & -1.07 & 0.42 & $-.10^{*}$ & & \\
\hline Step 3 & & & & .001 & $.04 * * *$ \\
\hline MG & -0.31 & 0.39 & -.03 & & \\
\hline PG & -0.06 & 0.34 & -.01 & & \\
\hline Step 4 & & & & $.01 *$ & $.05 * * *$ \\
\hline MG $\times P G$ & 2.55 & 1.35 & .29 & & \\
\hline $\mathrm{RT} \times \mathrm{MG}$ & -1.24 & 1.10 & -.11 & & \\
\hline $\mathrm{RT} \times \mathrm{PG}$ & 2.08 & 1.09 & $.13^{*}$ & & \\
\hline Step 5 & & & & .004 & $.05 * * *$ \\
\hline $\mathrm{MG} \times \mathrm{PG} \times \mathrm{RT}$ & -1.53 & 2.89 & -.08 & & \\
\hline \multicolumn{6}{|l|}{ Counseling $(n=568)$} \\
\hline Step 1: Control variables & & & & & .005 \\
\hline Supervisory mentor & 0.27 & 0.30 & .04 & & \\
\hline Relationship length & 0.03 & 0.02 & .06 & & \\
\hline Occupation & -0.11 & 0.19 & -.02 & & \\
\hline Step 2 & & & & .000 & .005 \\
\hline RT & -0.01 & 0.40 & -.00 & & \\
\hline Step 3 & & & & .000 & .005 \\
\hline MG & -0.08 & 0.38 & -.01 & & \\
\hline PG & 0.08 & 0.32 & .01 & & \\
\hline Step 4 & & & & $.017^{*}$ & .02 \\
\hline $\mathrm{MG} \times \mathrm{PG}$ & 0.43 & 1.29 & .05 & & \\
\hline $\mathrm{RT} \times \mathrm{MG}$ & 0.34 & 1.05 & .03 & & \\
\hline $\mathrm{RT} \times \mathrm{PG}$ & 3.10 & 1.04 & $.21 * *$ & & \\
\hline Step 5 & & & & .000 & .02 \\
\hline $\mathrm{MG} \times \mathrm{PG} \times \mathrm{RT}$ & -0.42 & 2.76 & -.02 & & \\
\hline Acceptance $(n=568)$ & & & & & \\
\hline Step 1: Control variables & & & & & $.03^{* *}$ \\
\hline Supervisory mentor & -0.10 & 0.19 & -.03 & & \\
\hline Relationship length & 0.05 & 0.01 & $.15^{* * *}$ & & \\
\hline Occupation & -0.05 & 0.11 & -.02 & & \\
\hline Step 2 & & & & $.02 * * *$ & $.05 * * *$ \\
\hline RT & -0.88 & 0.24 & $-.14 * * *$ & & \\
\hline Step 3 & & & & .003 & $.05^{* * *}$ \\
\hline MG & 0.19 & 0.23 & .04 & & \\
\hline PG & -0.27 & 0.20 & -.06 & & \\
\hline Step 4 & & & & $.01 * *$ & $.07 * * *$ \\
\hline $\mathrm{MG} \times \mathrm{PG}$ & 2.37 & 0.79 & $.46^{* *}$ & & \\
\hline $\mathrm{RT} \times \mathrm{MG}$ & -0.79 & 0.64 & -.12 & & \\
\hline $\mathrm{RT} \times \mathrm{PG}$ & 0.58 & 0.64 & .06 & & \\
\hline Step 5 & & & & .002 & $.07 * * *$ \\
\hline $\mathrm{MG} \times \mathrm{PG} \times \mathrm{RT}$ & 2.09 & 1.68 & .20 & & \\
\hline
\end{tabular}

Note. Dummy coding of predictors: Supervisory mentor: $1=$ supervisory, $0=$ not supervisor. Relationship type $(\mathrm{RT}): 1=$ formal mentor, $0=$ informal mentor. Mentor gender $(\mathrm{MG}): 1=$ male, $0=$ female. Protégé gender $(\mathrm{PG}): 1=$ male, $0=$ female.

$* p \leq .05$. ** $p<.01 . * * * p<.001$.

isfied with their mentors and were less likely to report that their mentor provided acceptance in their professional development. Male protégés with female mentors were also significantly less likely to report that their mentors provided challenging assignments and exposure than female protégés with male mentors.

Although male protégés with male mentors did not report more mentoring functions than other gender combinations, they did report more compensation, as shown in Table 5.
This indicated partial support for Hypothesis 8a. As predicted, male protégés with a history of primarily male mentors reported greater compensation than any other gender combination. However, male protégés with a history of male mentors did not receive more promotions than any other gender combination. Limited support was found for Hypothesis $8 \mathrm{~b}$; male protégés with a history of female mentors reported significantly less compensation than male protégés with male mentors, but predicted differences were 
Table 4

Summary of Hierarchical Regression Analysis for Variables Predicting Career Outcomes (Hypotheses 4 and 6b)

\begin{tabular}{|c|c|c|c|c|c|}
\hline Predictor and career outcome & $B$ & $S E$ & $\beta$ & $\Delta R^{2}$ & $R^{2}$ \\
\hline \multicolumn{6}{|l|}{ Promotions $(n=512$ ) } \\
\hline Step 1: Control variables & & & & & $.06^{* * * * * *}$ \\
\hline Position tenure & -0.01 & 0.001 & $-.23 * * *$ & & \\
\hline Career interruptions & 0.05 & 0.11 & .02 & & \\
\hline Occupation & 0.04 & 0.11 & .02 & & \\
\hline Supervisory mentors & 0.09 & 0.07 & .05 & & \\
\hline Length of relationships & -0.01 & 0.01 & -.03 & & \\
\hline Step 2: Hypothesis 4 & & & & .001 & $.07 * * *$ \\
\hline Prior relationship type & -0.43 & 0.50 & -.04 & & \\
\hline Step 3: Hypothesis $6 \mathrm{~b}$ & & & & .000 & $.07 * * *$ \\
\hline Prior gender of mentors & 0.09 & 0.24 & .01 & & \\
\hline \multicolumn{6}{|l|}{ Compensation $(n=508)$} \\
\hline Step I: Control variables & & & & & $.05 * * *$ \\
\hline Position tenure & 17.80 & 17.01 & .05 & & \\
\hline Career interruptions & -5148.51 & 1723.67 & $-.14 * *$ & & \\
\hline Occupation & 6044.48 & 1722.06 & $.16^{* * *}$ & & \\
\hline Supervisory mentors & 219.03 & 1169.03 & .01 & & \\
\hline Length of relationships & 211.41 & 111.82 & $.08^{*}$ & & \\
\hline Step 2: Hypothesis 4 & & & & $.01 * *$ & $.06 * * *$ \\
\hline Prior relationship type & -22552.85 & 7523.73 & $-.13 * *$ & & \\
\hline Step 3: Hypothesis 6b & & & & $.04 * * *$ & $.11 * * *$ \\
\hline Prior gender of mentors & 19503.37 & 3569.42 & $.22 * * *$ & & \\
\hline
\end{tabular}

Note. Higher values of prior supervisory mentors indicate greater proportion of supervisory mentors. Higher values of prior relationship type indicate greater proportion of formal mentors. Higher values of prior gender of mentors indicate greater proportion of male mentors.

${ }^{*} p \leq .05 .{ }^{* *} p \leq .01 .{ }^{* * *} p<.001$.

not found for the other gender combinations. Although male protégés with a history of female mentors had the lowest promotion rate of any gender combination, the difference was only significant when comparing this group with female protégés and male mentors.

An examination of the means in Table 5 reveals other provocative findings. Specifically, although female protégés with a history of primarily male mentors received significantly more promotions than male protégés with either male or female mentors, they did not receive more compensation. This suggests that compensation and promotion may be independent events for some groups. Another interesting result was that female protégés with a history of male mentors reported significantly greater compensation than female protégés with a history of female mentors. These women also reported significantly greater promotion rates than male protégés with a history of male mentors and those with a history of female mentors.

\section{Research Question and Other Gender Interactions}

The research question was assessed with the three-way interaction between mentor gender, protégé gender, and type of mentoring relationship (formal vs. informal). A significant three-way interaction was only found for the mentoring function of challenging assignments. A plot of this interaction revealed that for individuals in cross-gender relationships, informal mentors provided more challenging assignments than formal mentors, but for individuals with same-gender relationships, formal mentoring relationships provided more challenging assignments than informal relationships.

An examination of Tables 2 and 3 reveals that the effects of formal and informal mentoring relationships varied by the gender of the protégé in 5 of the 11 mentoring functions. The adjusted means for the significant two-way interactions revealed a similar pattern for 4 of the 5 mentoring functions. Specifically, the type of mentor influenced reports of mentor functions for female, but not for male protégés. Compared with female protégés with informal mentors, female protégés with formal mentors reported less coaching (formal $M=13.9$, informal $M=15.9$ ), role modeling (formal $M=13.4$, informal $M=14.8$ ), friendship (formal $M=14.9$, informal $M=16.8$ ), and social interactions (formal $M=6.8$, informal $M=9.0$ ). Male protégés, on the other hand, reported equivalent coaching (formal $M=15.0$, informal $M=15.2$ ), role modeling (formal $M=14.1$, informal $M=14.3$ ), friendship (formal $M=15.8$, informal $M=16.1$ ), and social interactions (formal $M=8.8$, informal $M=8.9$ ) with formal and informal mentors. The pattern was somewhat different for the counseling function. Like the other functions, female protégés reported receiving less counseling with formal mentors $(M=14.2)$ than in- 
Table 5

Adjusted Means for Study Variables by Gender Combination of Current and Prior Mentoring Relationships (Hypotheses 5, 7a,7b,8a, and 8b)

\begin{tabular}{|c|c|c|c|c|c|c|c|c|}
\hline \multirow[b]{2}{*}{ Variable } & \multicolumn{2}{|c|}{$\begin{array}{c}\text { Male protégés, male } \\
\text { mentors } \\
(n=208)\end{array}$} & \multicolumn{2}{|c|}{$\begin{array}{l}\text { Female protégés, } \\
\text { female mentors } \\
\qquad(n=105)\end{array}$} & \multicolumn{2}{|c|}{$\begin{array}{l}\text { Male protégés, } \\
\text { female mentors } \\
\qquad(n=23)\end{array}$} & \multicolumn{2}{|c|}{$\begin{array}{l}\text { Female protégés, } \\
\text { male mentors } \\
(n=220)\end{array}$} \\
\hline & $M$ & $S D$ & $M$ & $S D$ & $M$ & $S D$ & $M$ & $S D$ \\
\hline \multicolumn{9}{|l|}{ Current mentoring relationship } \\
\hline \multicolumn{9}{|c|}{ Overall satisfaction with mentor } \\
\hline Satisfaction & $23.6 \mathrm{a}$ & 4.1 & $23.6_{\mathrm{b}}$ & 4.0 & $21.4_{a, b, c}$ & 6.1 & $23.5_{c}$ & 4.5 \\
\hline \multicolumn{9}{|l|}{ Career development roles } \\
\hline Sponsor & 14.0 & 4.1 & 13.9 & 4.1 & 13.5 & 3.9 & 14.4 & 4.2 \\
\hline Coach & 14.9 & 3.6 & 15.4 & 3.6 & 13.8 & 4.7 & 15.2 & 3.6 \\
\hline Protect & 12.5 & 4.1 & 12.4 & 4.3 & 12.2 & 4.3 & 13.0 & 4.3 \\
\hline Challenge & 15.5 & 4.3 & 15.7 & 4.1 & $14.0_{\mathrm{a}}$ & 5.2 & $16.1_{3}$ & 4.1 \\
\hline Exposure & 15.1 & 3.9 & 14.8 & 4.1 & $13.6_{\mathrm{a}}$ & 4.4 & $15.5 \mathrm{a}$ & 4.2 \\
\hline \multicolumn{9}{|l|}{ Psychosocial roles } \\
\hline Friendship & 16.3 & 3.3 & 16.9 & 3.2 & 15.6 & 4.9 & 16.7 & 3.4 \\
\hline Social & 9.2 & 5.4 & $9.9 \mathrm{a}$ & 5.8 & 8.3 & 4.9 & $8.4_{\mathrm{a}}$ & 5.2 \\
\hline Parent & 4.3 & 3.2 & 3.2 & 3.3 & 4.0 & 3.1 & 4.0 & 2.9 \\
\hline Role model & 14.4 & 3.8 & 15.1 & 3.6 & 13.6 & 4.9 & 14.6 & 3.8 \\
\hline Counseling & 14.6 & 3.6 & 14.8 & 3.4 & 14.3 & 4.3 & 14.7 & 3.6 \\
\hline Acceptance & $17.9 \mathrm{a}$ & 2.2 & $18.4_{b}$ & 2.1 & $16.3_{\mathrm{a}, \mathrm{b}, \mathrm{c}}$ & 4.5 & $18.3_{\mathrm{c}}$ & 2.1 \\
\hline \multicolumn{9}{|l|}{ Prior mentoring relationship } \\
\hline \multicolumn{9}{|l|}{ Career outcomes } \\
\hline Compensation $(\times \$ 1,000)$ & $68.4_{\mathrm{a}, \mathrm{b}, \mathrm{c}}$ & 42.3 & $41.7_{\mathrm{a}, \mathrm{d}}$ & 19.4 & $\$ 46.5_{\mathrm{b}}$ & 13.6 & $\$ 50.8_{c, d}$ & 23.7 \\
\hline Promotion rate & $2.3_{b}$ & 2.2 & $2.5^{a+4}$ & 2.1 & $1.3 \mathrm{a}$ & 2.2 & $2.9_{\mathrm{a}, \mathrm{b}}$ & 2.1 \\
\hline
\end{tabular}

Note. Means adjusted for covariates and type of mentoring relationship. Means having the same subscript differ significantly at $p<.05$.

formal mentors $(M=14.8)$, but male protégés actually reported receiving more counseling from formal $(M=15.5)$ than informal $(M=14.2)$ mentors. In short, although protégés in formal relationships generally reported less mentoring functions than protégés in informal relationships, this relationship was not equivalent for men and women. Although the presence of a formal mentor was not associated with less mentoring functions for male protégés, formal mentoring was associated with less mentoring functions for female protégés.

Significant two-way interactions between mentor gender and protégé gender were also found for the coaching, friendship, and social roles functions. For coaching, although there were few differences between male and female protégés with male mentors $(M \mathrm{~s}=15.4$ and 15.7 , respectively), male protégés with female mentors reported significantly less coaching $(M=14.2)$ than female protégés with female mentors $(M=15.8)$. A similar pattern was found for the friendship function: Male and female protégés with male mentors reported equivalent friendship functions $(M \mathrm{~s}=16.2$ and 16.5 , respectively), but male protégés with female mentors reported significantly less friendship functions $(M=15.4)$ than female protégés with female mentors $(M=16.8)$. A plot of the interaction for social roles revealed a somewhat different pattern in that protégés in same-gender mentoring relationships reported more social interactions with their mentors than protégés in cross- gender relationships. The social functions means for women and men in same-gender relationships were 9.8 and 9.1, respectively, but the means for women and men in crossgender relationships were 8.2 and 8.1 .

\section{Post Hoc Analyses: Comparisons With Nonmentored Respondents}

One reasonable question that comes to mind when viewing these results is whether there were differences between those not mentored and those who had formal or informal mentoring relationships. This question replicates Chao et al.'s (1992) study, but it is also an extension of her study because we investigated promotion rates. We used an analysis of covariance (ANCOVA) to compare formal protégés, informal protégés, and nonmentored individuals on the career outcomes of compensation and promotion. Our results replicated Chao et al.'s (1992) findings. When controlling for occupation, tenure in position, and number of career interruptions, we found that employees with a history of primarily informal mentors received significantly more compensation $(M=\$ 56,629)$ than those without mentors $(M=\$ 51,389), F(2,924)=6.48, p<.01$, but there were no significant differences in compensation between nonmentored individuals and those with a history of formal mentoring relationships. As discussed earlier, when adding the additional control variables of length of mentoring re- 
lationship and supervisory status of mentors to our analyses, we found support for our hypothesis that protégés with a history of informal mentors would receive greater compensation $(M=\$ 56,629)$ than protégés with a history of formal mentors $(M=\$ 48,107)$. These results also replicated Chao et al.'s (1992) findings.

We also extended Chao's work by exploring the effect of mentoring on promotion rate. Consistent with prior research that compared informally mentored and nonmentored individuals (e.g., Dreher \& Ash, 1990; Scandura, 1992), an ANCOVA revealed that nonmentored individuals $(M=1.78)$ had significantly fewer promotions than those with a history of informal mentors $(M=2.55), F(2$, $924)=9.893, p<.0001$. However, nonmentored individuals $(M=1.78)$ did not significantly differ from those with a history of formal mentors $(M=2.04)$, with respect to the number of promotions received. As discussed earlier, individuals with a history of formal and informal mentors did not significantly differ in the number of promotions received.

In sum, those with a history of formal mentors did not receive greater career outcomes related to compensation or promotion than those lacking mentors. Those with a history of informal mentors received more compensation and promotions than nonmentored individuals and more compensation than those with formal mentors.

\section{Discussion}

\section{The Comparison of Formal and Informal Mentoring Relationships}

The first objective of our study was to provide a comprehensive test of mentor role theory (Kram, 1985a) by comparing the specific mentoring functions received by protégés in formal and informal mentoring relationships and the career outcomes associated with these relationships. We found that protégés with informal mentors received greater benefits than protégés with formal mentors. Protégés with informal mentors reported that their mentors provided more career development and psychosocial functions than protégés with formal mentors; significant differences favoring informal mentors were found in 9 of the 11 mentor roles. In line with these findings, protégés with informal mentors reported greater overall satisfaction with their mentors than protégés with formal mentors. Protégés with a history of informal mentors also earned significantly more than protégés with a history of formal mentors. Although protégés with a history of informal mentors also reported more promotions than protégés with formal mentors, the difference was not statistically significant.

These findings support the theoretical prediction that formal mentoring relationships provide less mentoring functions and are less effective than informal relationships (cf.
Kram; 1985a; Kram, 1986). Our findings were consistent with the significant findings of other research (Chao et al., 1992; Fagenson-Eland et al., 1997) and extend these studies by examining the full range of mentoring functions and career outcomes related to promotion and compensation. However, one question that comes to mind when viewing these results is why protégés in formal relationships received fewer benefits than protégés in informal relationships. As discussed in the introduction, existing theory points to a host of differences in the initiation, structure, and processes in formal and informal mentoring relationships. For example, formal relationships are short term and may have less identification, comfort, and motivation than informal relationships. Although these factors remain to be assessed directly in the future research, they can certainly explain why protégés with informal mentors in the present study reported more psychosocial functions and greater satisfaction with the relationship than protégés with formal mentors. However, the differences between formal and informal mentoring in compensation and career development roles may be due to selection; protégés who are selected or select informal relationships may be better performers than protégés who join formal mentoring programs. In other words, individuals who become informal protégés would have achieved more than those who become formal protégés even without their mentor's assistance. Individuals who become informal protégés may also be more career-driven and may seek and be more responsive to their mentor's career development functions than individuals who become formal protégés. Future research could take a longitudinal approach and collect performance measures to assess how much of the variance in protégés' career outcomes is due to the protégé's ability, the mentor's ability, or some combination of these two variables.

In support and extension of other research (Chao et al., 1992; Dreher \& Ash, 1990; Scandura, 1992), we found that those with informal mentors received more compensation and promotions than those without mentors, but no significant differences were found between those with formal mentors and nonmentored respondents. Although these findings indicate that the effects of formal mentoring on career outcomes may be quite limited, this does not automatically mean that formal mentors are without value; Chao et al., (1992), for example, found that protégés with formal mentors reported higher levels of some forms of organizational socialization than nonmentored individuals. Future research needs to expand the scope of career variables studied to capture the potential benefits of formal mentoring relationships. For example, formal mentoring relationships may be quite useful for immediate performance measures, such as on-the-job training, or as an impetus for the development of early career and performance goals. 


\section{The Impact of Gender Composition of the Relationship}

The second objective of our study was to provide a direct test of new theory on gender and mentoring (Ragins, 1997a) by assessing the relationship between the gender composition of the mentoring relationship and mentoring functions and outcomes. We also explored whether the gender composition of the relationship interacted with the type of relationship in influencing mentoring functions.

Our study revealed that the gender composition of the mentoring relationship affected reports of mentor functions and compensation. Although there was no support for the general hypothesis that same-gender relationships would report more psychosocial functions than cross-gender relationships, female protégés with female mentors were significantly more likely than female protégés with male mentors to engage in after-work, social activities with their mentors. This finding is congruent with other research indicating decreased reports of social interaction for women in cross-gender mentoring relationships (Ragins \& McFarlin, 1990). One explanation for this finding is that female protégés in cross-gender relationships may be reluctant to engage in after-work, social activities with their male mentors for fear that the interaction would be misconstrued as sexual in nature (Clawson \& Kram, 1984; Hurley \& Fagenson-Eland, 1996).

Although the presence of a male mentor was not associated with more career development functions, having a history of primarily male mentors was significantly related to compensation. Specifically, when controlling for position tenure, number of career interruptions, occupation, length of prior mentoring relationships, and whether those relationships involved formal or informal mentors and supervisory or nonsupervisory mentors, both male and female protégés with a history of male mentors reported more compensation than protégés with a history of female mentors. Moreover, female protégés with a history of male mentors earned significantly more than female protégés with a history of female mentors, suggesting that these findings reflect more than simple gender differences in protégé salary. These findings are congruent with recent research by Dreher and Cox (1996), who found a significant relationship between the presence of a White male mentor and compensation. The findings are also congruent with existing theory that posits a relationship between mentor power and outcomes of mentoring relationships (Ragins, 1997a, 1997b). According to this theory, male mentors can provide more career outcomes than female mentors because they have more power in organizations (Ragins \& Sundstrom, 1989).

Our study also found some support for emerging theory that explores outcomes associated with specific gender combinations of mentoring relationships. Diversified mentorship theory predicts that male protégés with male men- tors should receive the most benefits from their relationships, whereas male protégés with female mentors should receive the least benefits (Ragins, 1997a). We found some support for both propositions. Male protégés with male mentors did not report more mentoring functions than other gender combinations, but male protégés with a history of male mentors had greater compensation than any other gender combination. Although the relatively small sample size requires cautious interpretation, male protégés with female mentors did report less satisfaction with their mentors than any other gender combination and were less likely to report that their mentor provided acceptance in their professional development. Male protégés with female mentors were also less likely to report that their mentor provided challenging assignments and exposure in the organization than female protégés with male mentors. These findings support theoretical predictions related to gender differences in power and the mentor's ability to provide exposure, challenging assignments, and compensation for their protégés (Ragins, 1997a). The finding that male protégés with female mentors reported less acceptance from their mentor and less satisfaction with the relationship may also reflect personality differences among men who chose female, as opposed to male mentors. In a study of male graduate students, Infante (1990) found that men who chose female mentors were higher in self-esteem and the need for support and affiliation than men who chose male mentors. This suggests that even if female mentors give equivalent support as their male counterparts, they may still be viewed as providing insufficient support relative to the need of their male protégés. Future research could explore this possibility and examine other personality characteristics that predict male protégés choosing female mentors and vice versa.

An unexpected but striking finding of our study was that although female protégés with a history of male mentors received more promotions than their male counterparts, they received less compensation. This finding may reflect gender discrimination in organizations and is congruent with Stroh, Brett, and Reilly's (1992) finding that women managers were promoted as frequently as their male counterparts but were less likely to receive the compensation associated with their promotions. One important implication of this finding is that although male mentors may help female protégés advance in the organization, they may not be able to buffer their female protégés from biased compensation decisions.

The gender composition of the mentoring relationship not only influenced mentoring functions and outcomes but also moderated the relationship between the type of mentor and the challenging assignment mentoring function. Protégés in cross-gender relationships reported that their mentors provided less challenging assignments with formal as compared with informal relationships. Those in same-gender relationships, however, actually reported receiving more challenging assignments from their mentors when the men- 
tor was formally assigned. This suggests that same-gender mentoring relationships should be used in formal mentoring programs that are aimed at developing the protégé's job performance by giving them stretch assignments.

A surprising finding of our study was that the benefits of formal and informal mentoring varied by protégé gender. Male protégés with formal mentors not only reported more counseling than female protégés with formal mentors, but they also reported more of this function than both male and female protégés with informal mentors. It is clear that for the counseling function, male protégés stand to gain the most from having a formal mentor. Although the presence of a formal mentor did not have an adverse effect on male protégés, it reduced reports of coaching, role modeling, social, counseling, and friendship functions for female protégés. This suggests that female protégés may have the least to gain from entering a formal mentoring relationship.

\section{Limitations of This Study}

Several limitations of this study should be mentioned. First, although retrospective measures of mentoring history are more appropriate than static measures for assessing the relationship between mentoring and career outcomes, retrospective measures are self-report measures that are susceptible to recall and other biases. A longitudinal approach would certainly be preferable for studying mentoring history efforts, and future research should use longitudinal data.

A second limitation of this study was the relatively small sample of male protégés with female mentors. We recognized the difficulty in obtaining this sample when we viewed prior research; the Ragins and McFarlin (1990) study, for example, had only 11 of these relationships out of a sample of 510 employees. These researchers observed that studies of male-dominated organizations and occupations are unlikely to produce adequate samples of female mentors with male protégés. With this caveat in mind, we explicitly sought to obtain gender balance in our study by using an equally weighted sample of social workers, journalists, and engineers. It is telling that of the 1,162 respondents, we had only 24 male protégés with female mentors. Our tentative finding of less mentoring functions and outcomes associated with these relationships may be due not just to the rarity of female mentors but also to the dynamics of the relationship. Future research could explore in greater depth the interpersonal dynamics in female mentor-male protégé relationships.

A third potential limitation of our study came about as a result of our attempt to obtain balance in the gender composition of the mentoring relationships in our sample. Specifically, although a sample of social workers, journalists, and engineers increases the probability of different gender combinations of mentoring relationships, at the same time it raises the possibility that occupational differences in mentoring may account for some of the findings in our study. As a point in fact, social workers were more likely to have formal mentors than journalists, $\chi^{2}(1, N=614)=13.44$, $p<.01$, and female mentors were less likely to be reported among engineers than the other two occupations, $\chi^{2}(1, N=$ $615)=37.56, p<.001$. With this in mind, we controlled for occupation by entering it in the first step of all of our hierarchical regression analyses and by using means that were adjusted for occupation in our means tests. We also reran the analyses separately for each of the three occupations and found generally equivalent results. Nevertheless, occupational differences may still account for some of the findings of the present study.

Finally, although regression analyses allowed us to hierarchically control for mentoring and organizational variables, and the type of mentor in separate steps, the use of many separate regression analyses results in restricted control over experiment-wide Type I error. Accordingly, marginal levels of significance were not reported. We also reanalyzed the data using a multivariate analysis of covariance (MANCOVA) and ANCOVA analyses, and the regression results were replicated with one exception: The threeway interaction between mentor gender, protégé gender, and type of mentor for the dependent variable of challenging assignments did not maintain its significance in the MANCOVA analyses.

\section{Implications for Organizations}

One clear implication of this study is that formal mentoring programs should not be considered as a substitute for informal mentoring relationships but should be offered in partnership with informal relationships. Formal mentors are probably most effective when they approximate informal mentors in as many ways as possible. Along those same lines, where possible, formal mentoring programs should mimic the development of informal relationships. One example of this is when the organization identifies pools of potential mentors and protégés, trains these individuals in the skills necessary for effective mentoring relationships, but then allows them to select their own mentoring partners (cf. Forret, Turban, \& Dougherty, 1996). Another suggestion is for organizations to use formal mentoring relationships as a springboard for the development of informal relationships; protégés with formal mentors would be encouraged to identify and select informal mentors while in the last stage of their formal mentoring relationship. It is important for organizations to avoid sending the implicit message that once a protégé has an assigned mentor, this mentor is sufficient and that they should not attempt to gain an informal mentor. One way to accomplish this is for training programs to include strategies and skills for developing relationships with informal mentors. 
A second key implication of this study is that although formal mentoring relationships are less effective than informal relationships, they may be even less effective for female protégés. This is an important issue because formal mentoring programs are being developed as part of emerging diversity initiatives, and many are aimed at helping women break through gender-related barriers to advancement (Catalyst, 1993; Herry, 1994; Kram \& Hall, 1996; Scott, 1992). It would therefore be misleading for organizations to offer formal mentors as a substitute for informal relationships, or for them to suggest, directly or indirectly, that the relationships are interchangeable. Instead, the results of this study suggest that for optimal promotion rate, female protégés should develop informal mentoring relationships with male mentors. However, even these male mentors are no panacea, since promotion and compensation appear to be independent events for women in organizations (Stroh et al., 1992).

\section{Future Research}

This study examined the relationship between gender, the type of mentoring relationship, and mentoring functions and outcomes. Although we found direct effects between gender, the type of mentoring relationship and compensation, it was beyond the scope of this study to examine whether mentoring functions mediate these relationships. A review of the bivariate correlations suggests that the relationship between mentoring functions and career outcomes is relatively weak and varies by the type of function. Future research needs to examine mediational effects and the relationship between mentoring functions and career and organizational outcomes. If the mentor's behaviors or functions do not mediate the relationship between the type of relationship and career outcomes, perhaps other mediators that have not been studied are operative, such as the protégé's behaviors in the relationship or the interaction between mentor and protégé behavior.

An interesting finding in our study was that supervisory mentors provided more career development functions than nonsupervisory mentors for four of the five career development functions (sponsorship, protection, challenging assignments, and exposure) but did not differ in provision of psychosocial functions. These findings, which replicate Ragins and McFarlin's (1990) study, suggest that supervisory mentors may have a better assessment of the career needs of their protégés than nonsupervisory mentors and may be in a better position to provide career development functions because of proximity, contact, and control over work assignments. However, although proximity may allow supervisory mentors to provide more career development functions, it may not allow them to become closer to their protégés. Supervisory mentors may hold back from providing psychosocial functions because intimacy and friendship in their mentoring relationships may conflict with their supervisory roles. These relationships should be explored in future research. The significance of the supervisory mentoring variable also illustrates the importance of including mentoring control variables, particularly when investigating gender effects in mentoring relationships (cf. Ragins, 1999).

Finally, future research should explore the effects of different historical combinations of mentoring relationships on career outcomes and processes. In this study, we examined separately the historical effects of gender composition and the type of mentor on career outcomes. The results of this study could be used as a foundation for the development of a theoretical model that explains how the history of various combinations of mentoring relationships combine to affect career outcomes. This model could examine how gender composition interacts with type of mentor (formal, informal, supervisory, and nonsupervisory) in affecting a host of career and organizational outcomes. Which types of relationships are critical in which career stages for the protégé and the mentor? What individual, interpersonal and organizational factors affect the historical composition of mentoring relationships? Which types of compositions are most effective for which types of situations? One point that is driven home by the present study is that the outcomes and processes in mentoring relationships are influenced by the gender of the members of the relationship. Future studies, therefore, need to use large enough samples that allow for an in-depth exploration of these important, but complex, gender interaction effects.

\section{References}

Allen, T. D., Poteet, M. L., \& Burroughs, S. M. (1997). The mentor's perspective: A qualitative inquiry and future research agenda. Journal of Vocational Behavior, 51, 70-89.

Arthur, M. B., \& Rousseau, D. M. (Eds.) (1996). The boundaryless career: A new employment principle for a new organizational era. New York: Oxford University Press.

Beggs, J. M., \& Doolittle, D. C. (1993). Perceptions now and then of occupational sex typing: A replication of Shinar's 1975 study. Journal of Applied Social Psychology, 23, 1435-1453.

Bragg, A. (1989). Is a mentor program in your future? Sales and Marketing Management, 141, 54-59.

Burke, R. J., \& McKeen, C. A. (1989). Developing formal mentoring programs in organizations. Business Quarterly, 53, 7699.

Burke, R. J., \& McKeen, C. A. (1997). Benefits of mentoring relationships among managerial and professional women: $A$ cautionary tale. Journal of Vocational Behavior, 51, 43-57.

Byrne, D. (1971). The attraction paradigm. New York: Academic Press.

Catalyst. (1993). Mentoring: A guide to corporate programs and practices. New York: Author.

Chao, G. T. (1997). Mentoring phases and outcomes. Journal of Vocational Behavior, 51, 15-28.

Chao, G. T., Walz, P. M., \& Gardner, P. D. (1992). Formal and informal mentorships: A comparison on mentoring functions 
and contrast with nonmentored counterparts. Personnel Psychology, 45, 619-636.

Clawson, J. G., \& Kram, K. E. (1984). Managing cross-gender mentoring. Business Horizons, 27, 22-32.

Dillman, D. A. (1978). Mail and telephone surveys: The total design method. New York: Wiley.

Douglas, C. A. (1997). Formal mentoring programs in organizations: An annotated bibliography. Greensboro, NC: Center for Creative Leadership.

Dreher, G. F., \& Ash, R. A. (1990). A comparative study of mentoring among men and women in managerial, professional, and technical positions. Journal of Applied Psychology, 75, $539-546$.

Dreher, G. F., \& Cox, T. H., Jr. (1996). Race, gender, and opportunity: A study of compensation attainment and the establishment of mentoring relationships. Journal of Applied Psychology, 81, 297-308.

Ensher, E. A., \& Murphy, S. E. (1997). Effects of race, gender, perceived similarity, and contact on mentor relationships. Journal of Vocational Behavior, 50, 460-481.

Erikson, E. H. (1963). Childhood and society. New York: W. W. Norton.

Fagenson, E. A. (1989). The mentor advantage: Perceived career/ job experiences of protégés versus non-protégés. Journal of Organizational Behavior, 10, 309-320.

Fagenson-Eland, E. A., Marks, M. A., \& Amendola, K. L. (1997). Perceptions of mentoring relationships. Joumal of Vocational Behavior, 51, 29-42.

Forret, M. L., Turban, D. B., \& Dougherty, T. W. (1996). Issues facing organizations when implementing formal mentoring programmes. Leadership \& Organization Development Journal, 17, 27-30.

Gaskill, L. R. (1993). A conceptual framework for the development, implementation, and evaluation of formal mentoring programs. Journal of Career Development, 20, 147-160.

Geiger-DuMond, A. H., \& Boyle, S. K. (1995). Mentoring: A practitioner's guide. Training and Development, 49, 51-54.

Gray, W. A. (1988). Developing a planned mentoring program to facilitate career development. Career Planning and Adult Development Journal, 4, 9-16.

Hall, D. T., \& Mirvis, P. H. (1996). The new protean career: Psychological success and the path with a heart. In D. T. Hall (Ed.), The career is dead-Long live the career: A relational approach to careers (pp. 15-45). San Francisco: Jossey-Bass.

Herry, W. (1994). Corporate mentoring can break the glass ceiling. HRFocus, 71, 17.

Hunt, D. M., \& Michael, C. (1983). Mentorship: A career training and development tool. Academy of Management Review, 8, 475-485.

Hurley, A. E., \& Fagenson-Eland, E. A. (1996). Challenges in cross-gender mentoring relationships: Psychological intimacy, myths, rumours, innuendoes and sexual harassment. Leadership \& Organization Development Journal, 17, 42-49.

Infante, R. A. (1990). Gender and the mentoring process: Comparison of men who choose male or female mentors [CD-ROM]. (Abstract from: ProQuest File: Dissertation Abstracts Item: 9016901)

Kalbfleisch, P. J., \& Davies, A. B. (1993). An interpersonal model for participation in mentoring relationships. Western Journal of Communication, 57, 399-415.

Keele, R. L., Buckner, K., \& Bushnell, S. J. (1987). Formal mentoring programs are no panacea. Management Review, 76, 67-68.

Koberg, C. S., Boss, R. W., Chappell, D., \& Ringer, R. C. (1994). Correlates and consequences of protégé mentoring in a large hospital. Group and Organization Management, 19, 219-239.

Kram, K. E. (1983). Phases of the mentor relationship. Academy of Management Journal, 26, 608-625.

Kram, K. E. (1985a). Mentoring at work: Developmental relationships in organizational life. Glenview, IL: Scott Foresman.

Kram, K. E. (1985b). Improving the mentoring process. Training and Development Journal, 39, 40-43.

Kram, K. E. (1986). Mentoring in the workplace. In D. T. Hall (Ed.), Career development in organizations (pp. 160-201). San Francisco: Jossey-Bass.

Kram, K. E., \& Bragar, M. C. (1992). Development through mentoring: A strategic approach. In D. Montross \& C. Shinkman (Eds.), Career development: Theory and practice (pp. 221-254). Springfield, IL: Charles C Thomas.

Kram, K. E., \& Hall, D. T. (1996). Mentoring in a context of diversity and turbulence. In E. E. Kossek \& S. A. Lobel (Eds.), Managing diversity: Human resource strategy for transforming the workplace (pp. 108-136). Cambridge, MA: Blackwell.

Levinson, D. J., Darrow, C. N., Klein, E. B., Levinson, M. H., \& McKee, B. (1978). The seasons of a man's life. New York: Knopf.

Murray, M. (1991). Beyond the myths and magic of mentoring: How to facilitate an effective mentoring program. San Francisco: Jossey-Bass.

Neter, J., \& Wasserman, W. (1974). Applied linear statistical models: Regression, analysis of variance, and experimental design. Homewood, IL: Irwin.

Noe, R. A. (1988). An investigation of the determinants of successful assigned mentoring relationships. Personnel Psychology, 4l, 457-479.

Olian, J. D., Carroll, S. J., \& Giannantonio, C. M. (1993). Mentor reactions to protégés: An experiment with managers. Journal of Vocational Behavior, 43, 266-278.

Olian, J. D., Carroll, S. J., Giannantonio, C. M., \& Feren, D. B. (1988). What do protégés look for in a mentor? Results of three experimental studies. Journal of Vocational Behavior, 33, 1537.

Ostroff, C., \& Kozlowski, S. W. (1993). The role of mentoring in the information gathering processes of newcomers during early organizational socialization. Journal of Vocational Behavior, 42, 170-183.

Paine, F. (1986). Students, media professionals are paired in mentor program. Journalism Educator, 11, 24-25.

Phillips-Jones, L. (1983). Establishing a formalized mentoring program. Training and Development Journal, 37, 38-42.

Ragins, B. R. (1989). Barriers to mentoring: The female manager's dilemma. Human Relations, 42, 1-22.

Ragins, B. R. (1997a). Diversified mentoring relationships in organizations: A power perspective. Academy of Management Review, 22, 482-521. 
Ragins, B. R. (1997b). Antecedents of diversified mentoring relationships. Journal of Vocational Behavior, 51, 90-109.

Ragins, B. R. (1999). Where do we go from here, and how do we get there? Methodological issues in conducting research on diversity and mentoring relationships. In A. J. Murrell, F. J. Crosby, \& R. J. Ely (Eds.), Mentoring dilemmas: Developmental relationships within multicultural organizations (pp. 227247). Mahwah, NJ: Erlbaum.

Ragins, B. R., \& Cotton, J. (1991). Easier said than done: Gender differences in perceived barriers to gaining a mentor. Academy of Management Journal, 34, 939-951.

Ragins, B. R., \& McFarlin, D. (1990). Perception of mentor roles in cross-gender mentoring relationships. Joumal of Vocational Behavior, 37, 321-339.

Ragins, B. R., \& Scandura, T. A. (in press). Burden or blessing? Expected costs and benefits of being a mentor. Journal of Organizational Behavior.

Ragins, B. R., \& Sundstrom, E. (1989). Gender and power in organizations: A longitudinal perspective. Psychological Bulletin, 105, 51-88.

Scandura, T. A. (1992). Mentorship and career mobility: An empirical investigation. Journal of Organizational Behavior, 13, 169-174.

Scandura, T. A., \& Katerberg, R. J. (1988, August). Much ado about mentors and little ado about measurement: Development of an instrument. Paper presented at the meeting of the National Academy of Management, Anaheim, CA.

Scott, M. E. (1992). Designing effective mentoring programs: Historical perspectives and current issues. Joumal of Humanistic Education and Development, 30, 167-177.
Smith, J. M., Chase, P. N., \& Byrd, J., Jr. (1986). A formalized mentor system in an educational setting. Engineering Education, 76, 216-218.

Stroh, L. K., Brett, J. M., \& Reilly, A. H. (1992). All the right stuff: A comparison of female and male managers' career progression. Journal of Applied Psychology, 77, 251-260.

Taibbi, R. (1983). Supervisors as mentors. Social Work, 28, $237-$ 238.

Tajfel, H. (1978). The achievement of group differentiation. In H. Tajfel (Ed.), Differentiation between social groups: Studies in the social psychology of intergroup relations (pp. 77-98). London: Academic Press.

Tsui, A., Egan, T. D., \& O'Reilly, C. A. (1992). Being different: Relational demography and organizational attachment. Administrative Science Quarterly, 37, 549-579.

Tsui, A. S., \& O'Reilly, C. A. (1989). Beyond simple demographic effects: The importance of relational demography in superiorsubordinate dyads. Academy of Management Journal, 32, 402423.

U.S. Department of Commerce. (1996). Statistical Abstract of the United States 1996. Washington, DC: Author.

Viator, R. E., \& Scandura, T. A. (1991). A study of mentor-protégé relationships in large public accounting firms. Accounting Horizons, 5, 20-30.

Whitely, W., Dougherty, T. W., \& Dreher, G. F. (1991). Relationship of career mentoring and socioeconomic origin to managers' and professionals' early career progress. Academy of Management Journal, 34, 331-351.

Zey, M. G. (1985). Mentor programs: Making the right moves. Personnel Joumal, 64, 53-57. 


\section{Appendix}

\section{Instruments Used in Study}

Mentor Role Instrument (Ragins \& McFarlin, 1990)

\section{My Mentor:}

\section{(SPONSOR)}

helps me attain desirable positions.

uses his/her influence to support my advancement in the organization. uses his/her influence in the organization for my benefit.

\section{(COACH)}

helps me learn about other parts of the organization.

gives me advice on how to attain recognition in the organization.

suggests specific strategies for achieving career aspirations.

\section{(PROTECT)}

protects me from those who may be out to get me.

"runs interference" for me in the organization.

shields me from damaging contact with important people in the organization.

(CHALLENGE)

gives me tasks that require me to learn new skills.

provides me with challenging assignments.

assigns me tasks that push me into developing new skills.

(EXPOSURE)

helps me be more visible in the organization.

creates opportunities for me to impress important people in the organization.

brings my accomplishments to the attention of important people in the organization.

\section{(FRIENDSHIP)}

is someone I can confide in. provides support and encouragement. is someone I can trust.

(SOCIAL)

and I frequently get together informally after work by ourselves. and I frequently socialize one-on-one outside the work setting. and I frequently have one-on-one, informal social interactions.

\section{(PARENT)}

is like a father/mother to me.

reminds me of one of my parents.

treats me like a son/daughter.

(ROLE MODEL)

serves as a role-model for me.

is someone I identify with.

represents who I want to be.

(COUNSELING)

serves as a sounding board for me to develop and understand myself. guides my professional development.

guides my personal development.

(ACCEPTANCE)

accepts me as a competent professional.

sees me as being competent.

thinks highly of me.

Satisfaction With Mentor Scale

\author{
My Mentor: \\ is someone I am satisfied with \\ fails to meet my needs. \\ disappoints me (reverse-scored) \\ has been effective in his/her role.
}

Note. Both instruments were measured using a 7-point Likert scale with responses ranging from strongly disagree (1) to strongly agree (7). Items were randomly ordered in the survey.

Received December 23, 1997

Revision received September 21, 1998

Accepted September 28, 1998 